\title{
Scrum Framework and Health Solutions: Management and Results
}

\author{
Gisele TORRENTE ${ }^{\mathrm{a}, 1}$, Thiago Queiroz de SOUZA ${ }^{\mathrm{a}}$, Lie TONAKI ${ }^{\mathrm{a}}$, Ana Paula \\ CARDOSO $^{\mathrm{a}}$, Leon MANICKCHAND Junior ${ }^{\mathrm{a}}$ and Geferson Oliveira da SILVA ${ }^{\mathrm{a}}$ \\ a Amazon State University, Brazil
}

\begin{abstract}
Introduction: Technology arrives aiming at bringing benefits to society, with aspects applied to health such as Information and Communication Technologies (ICTs). Developing a technology solution requires methodological rigor and systematic instructional design. Method: This experience report method used the Agile methodology for management and control of results in the development of Information and Communication Technologies. Results: The Agile methodology was adopted using the Scrum framework, involving people, artifacts, and ceremonies. The Scrum team was consisted of multidisciplinary professionals and undergraduate students. Artifacts are comprised of product backlog, sprints, sprint backlog, time-box, ready concept, and release burn-down. Conclusions: The adoption of the Scrum methodology helps with the integration of roles and knowledge to a project. Moreover, it efficiently helps carrying out activities by allowing careful analysis of each stage with regard to quality, technology, and implementation.
\end{abstract}

Keywords. Technology; point-of-care system; health sciences, technology, and innovation management; information technology; nursing, information system

\section{Introduction}

Technology arrives aiming at bringing benefits to society, with aspects applied to health such as Information and Communication Technologies (ICTs). ICTs provide patient care with the use of tools, disseminating information easily, in real time and with integration among professionals or in the professional/patient relationship. It is currently used in hospitals as electronic medical records, management systems and support information systems for clinical decision-making [1-3].

Developing a technology solution requires methodological rigor and a associated with the program, those responsible for the solution use Agile methodologies to manage the development stages [6,7].

Agile methodologies are configured by having short cycles with iterative development and contribute to managing physical digital solutions and, in the proposals, Lean, Kanban, Smart and Scrum are cited with different origins and main objectives. [8, 9].

Scrum is a framework that deals and solves complex and adaptive problems, to ensure productivity and delivery of products with the best possible value. Scrum is light,

\footnotetext{
${ }^{1}$ Corresponding Author, Gisele Torrente, Nursing Department, School of Health Sciences, Amazon State University (UEA), Manaus-Amazon, Brazil; E-mail: gtorrente@uea.edu.br.
} 
simple to understand, but difficult to master. It is based on empirical theories of process control, which is defined as decisions being made based on what is known, with interactive incremental approach focusing on predictability and risk control. [7,10].

In Scrum, a list of desired product features (Product Backlog) is initially defined at the start of the project. Projects are divided into sprints (from one to four weeks), and in each sprint a set of activities. [8] At the beginning of each sprint cycle there is a cycle planning meeting, where are a list prioritized and activities. Daily meetings with the teams are brief to identifying impediments and prioritizing the new day's work. At the end of the cycle, the team presents the functionalities implemented while also doing the retrospective and the planning of the next sprint. [9]

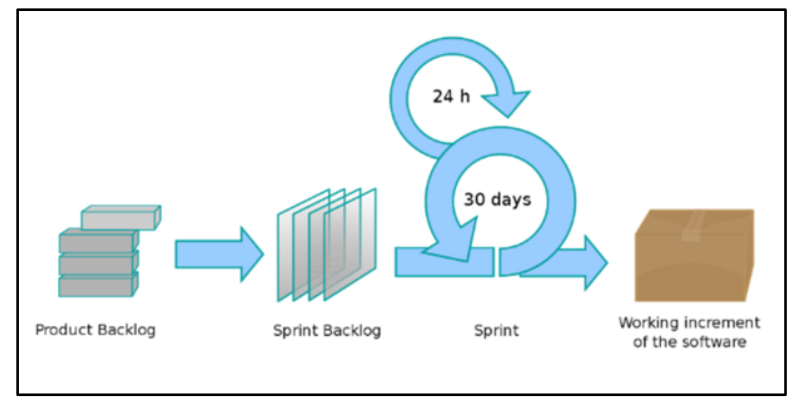

Figure 1. Scrum process.

It consists of roles (product owner, Scrum master, development team), artifacts (product backlog, sprint, sprint backlog, time-box, release burndown), and ceremonies (sprint planning meeting, daily scrum, sprint retrospective, sprint review meeting). $[7,10]$.

This article aims to describe the applicability of the Scrum method in the development of an Information and Communication Technology applied to health with a focus on the benefits of socializing knowledge and commitment to interdisciplinarity.

\section{Method}

This unique and descriptive case report described the application of the Scrum method in the development and monitoring of an Information and Communication Technology applied to health. The development of ICTs takes place at the Amazon State University. Their resources include partnerships with private companies and support from the national laws of fiscal incentive.

The case report is a qualitative and descriptive research method, in which the authors are free to investigate a phenomenon within the current and real context to which it is embedded. It can be defined and applied to individuals, group of people or less defined as decisions, programs, implementation processes, or organizational changes. The stages follow the logic of grouping the information, analyzing and interpreting the information [11-12].

Carrying out the project obeyed the ethical precepts involving research with human beings and obtained favorable opinion of a Research Ethics Committee, under Protocol 71308717.5.0000.5016. 


\section{Result}

The development of ICT began in May 2019 and it was decided to use a Scrum methodology because it was well understood by the team, and comprehensive training was provided by the company.

\subsection{Information and Communication Technology}

The solution covers the web system and mobile system, with the purpose of managing and integrating the pre-hospital care service.

\subsection{From the Composition of the Team-Papers}

The team is composed by:

Health team: the product owner, $\mathrm{PhD}$ in nursing and is in charge of idealization of the ICT; two nurses (Master's degree), a physician (Master's degree), an undergraduate student in nursing, a postgraduate program student in nursing, and two undergraduate students in medicine.

Developer team: the Scrum master Master's degree in computer science and ensures the proper application of Scrum in all its stages. Among the developers, two of them are working on the front-end (undergraduate degree in information system and computer science), one on the back-end (graduate degree in computer engineering), one is a designer (graduate degree in graphic designer technology), another is a developer for mobile system (computer engineering), and one is a tester (control and automation engineering).

\subsection{Development-Artifacts and Ceremonies}

The product backlog is composed of two large blocks (web and mobile), initially conceived with five users that, after meeting with the end customer, is composed of web system (three users) and mobile system (five users). The 114 users' histories were delimited according to the professional assignment of each user and care protocols adopted by the pre-hospital care service, which ultimately composed the use of a case diagram as part of the documentation of this technology.

The Scrum's central axis is called sprint. The sprint backlog of this project consists of 44 sprints that the developer team must deliver within a 30-day time-box. In addition to the deadline, sprints must be delivered according to priorities established by a product owner (PO) at the time of a sprint planning meeting. It should be noted that a timebox, once defined, should not be changed.

The Scrum team has short-term meetings called daily scrum, which are used to identify all tasks carried out in the past 24 hours. Daily scrum is also used for answering questions about yesterday, today and possible impediments and/or challenges on what needs to be done going forward. It finally allows for a collective understanding of sprint status and the established concept of done across three phases: analysis, development, and testing.

At the end of this stage, the activity delivery time (release burndown), identification of strengths, weaknesses and improvement strategies (sprint retrospective) were documented. All participants were gathered at the time for approval the product and confirmed the adaptations (sprint review). 
Other artifacts applied to the development were release burndown, which aimed to monitor the performance within the agreed upon time-box. This effort was done to confirm that the group within the sprint retrospective successfully identified the strengths, weaknesses and areas for improvement at the end of each sprint and sprint review meeting.

\section{Discussion}

This strategy for presenting the stages of development is found in articles and identified as an important phase of socializing positive experiences and applicable to the process of developing technological solutions [17-19]. The Agile Scrum methodology was chosen based on its versatility. [20,21].

Scrum allows autonomy, flexibility by associating well-defined artifacts, roles, and ceremonies without losing focus on the stages, time period and quality of deliverables. The increase in other strategies within Scrum is seen as positive with KANBAN and Agile Word-Oriented Systems Engineering (AWOSE) each having distinct functions that give quality in different aspects to product development $[22,23]$.

For team building, it was important to have people with different technical and nontechnical skill sets such as leadership ability, communication, and teamwork. Individuals with multi-skills are required and well accepted successfully for the use of Scrum $[10,24]$.

The technological proposals offered by nurses reflect on the support for safe decision-making and the idealization of the product by a nursing professional and show the role of the category in a scenario of technological solutions for health. The authors also point out the importance of the presence of nurses and their contribution based on scientific knowledge applied to patient safety as well as leadership capacity in the conduct of processes and projects $[3,25,26]$.

During the application of the Scrum method in the development of this ICT, it is pointed out that team maturation requires time, component team maintenance is at high risk in the project, participant involvement and commitment must be nurtured frequently. It takes commitment from everyone to achieve the schedule of activities and successful completion of all deliverables, avoiding delays for the project in addition to a good relationship between the Scrum team. Flexibility in decisions during ceremonies can also ensure a better result.

\section{Conclusions}

The idealization, development, improvement and incorporation of innovative technologies in health is a reality in a fast progression. Using Agile methodologies validated during development gives expertise, agility, and quality to deliverables. The selection of Team Members, product knowledge, commitment and involvement in the ceremonies collaborate with the success in the application of Scrum.

For the Information and Communication Technology proposed in this article, it is believed that the application of Scrum Agile methodology positively contributed to all stages of its development 


\section{References}

[1] Barr N, Vania D, Randall G, Mulvale G. Impact of information and communication technology on interprofessional collaboration for chronic disease management: A systematic review. J Heal Sevices Reseach Polcy. 2017;0(0):1-8.

[2] Rouleau G, Gagnon MP, Côté J, Payne-Gagnon J, Hudson E, Dubois CA. Impact of Information and Communication Technologies on Nursing Care: Results of an Overview of Systematic Reviews. Journal of Medical Internet Research [Internet]. Journal of Medical Internet Research; 2017;19(4):e122. Available from: https://dx.doi.org/10.2196/jmir.6686

[3] Starkweather A, Jacelon CS, Bakken S et al. The use of technology to support precision health in nursing science. J Nurs Scholarsh. 2019;51(6):614-23.

[4] World Health Organization. Recommendations on digital interventions for health system strengthening Summary of findings and GRADE tables. Genebra; 2019. 175 p.

[5] Comitê Gestor da Internet no Brasil. Tic saúde - Pesquisa sobre o uso de tecnologias de informação e comunicação nos estabelecimentos brasileiros. São Paulo; 2019. 408 p.

[6] Barra DC, Paim SM, Dal Sasso GT, Colla GW. Métodos para desenvolvimento de aplicativos móveis em saúde: revisão integrativa da literatura. Texto Context - Enferm. 2017;26(4):1-12.

[7] Silva GM da, Paula SL de, Granja BC de A. Utilização do Scrum para Desenvolvimento de um banco público de práticas e soluções em saúde. In: Encontro de Estudos sobre tecnologia, ciência e gestão da informação. 2019. p. 19.

[8] Rooij SW Van. Scaffolding project-based learning with the project management body of knowledge. Computers \& Education Scaffolding project-based learning with the project management body of knowledge (PMBOK). Comput Educ [Internet]. Elsevier Ltd; 2019;52(1):210-9.Available rom:http://dx.doi.org/10.1016/j.compedu.2008.07.012

[9] Silva CM de A e, Gobbo D, Dudyk J, Friedemann R, Brancher GG. Teste de usabilidade clássico vx. lean ux test: aplicabilidade dos métodos de avaliação. LOGO. 2017;6(2):106-21.

[10] Schwaber K, Sutherland J. Guia do Scrum TM. 2013. 19 p.

[11] Meirinhos M, Osório A. O estudo de caso como estratégia de investigação em educação. EDUSER Rev edicação. 2010;2(2):49-65.

[12] Mascarenhas AO, Vasconcelos FC de, Vasconcelos IFG de. Impactos da Tecnologia na Gestão de Pessoas - um Estudo de Caso. RAC. 2005;9(1):125-47.

[13] Conselho Nacional de Saúde. Resolução no 466. In Brasília: Brasil; 2012. p. 12.

[14] Grossi LM, Pisa IT, Marin H de F. Oncoaudit: desenvolvimento e avaliação de aplicativo para enfermeiros auditores. Acta Paul Enferm. 2014;27(2):179-85.

[15] Polit DF, Beck CT. Essentials of nursing research appraising evidence for nursing practice. 7a ed. Surrena H, Kogut H, Ewan H, Kors E, Kinsella M, editors. Lippincott Williams \& Wilkins; 2016. 626 p.

[16] Gottlieb GJ, Ragaz A, Vogel J V et al. A preliminary communication on extensively disseminated Kaposi's sarcoma un young homosexual men. Am Journa Dermatopathol. 1981;3(2):111-4.

[17] Yoshida WB. Redação do relato de caso. J Vasc Bras. 2007;6(2):112-3.

[18] Devadiga N. A case study on software requirements engineering using the FBI Virtual Case File Project Report. Int J Adv Eng Res Sci. 2018;6495(4):7-9.

[19] Nelson SD, Fiol G Del, Hanseler H, Crouch BI, Cummins MR. A case report of refining user requirements for a health information exchange dashboard. Appl Clin Inform. 2016;7:22-32.

[20] Disque K. Advanced cardiac life support - provider handbook. Las Vegas: Satori Continuum Publishing; 2020. 73 p.

[21] Trauma AC of S-C on. Suporte Vital de Trauma Prehospitario. 9a ed. Burlington: Associação Nacional de Técnicos Médicos de Emergência; 2019. 1245 p.

[22] Hidalgo ES. Adapting the scrum framework for agile project management in science : Case study of a distributed research initiative. Heliyon [Internet]. Elsevier Ltd; 2019;5(e01447):32. Available from: https://doi.org/10.1016/j.heliyon.2019.e01447

[23] Strenge B, Schack T. AWOSE - A process model for incorporating ethical analyses in agile systems engineering. Sci Eng Ethics [Internet]. Springer Netherlands; 2020;26(2):851-70. Available from: https://doi.org/10.1007/s11948-019-00133-z

[24] Flin R, O'Connor P, Crichton M. Safety at the sharp end: A guide to non-technical skills. CRC Press. Boca Raton: Taylor \& Francis Group; 2008. 330 p.

[25] Cruz JR da, Gonçalves LS, Giacomo APM de A de. Metodologia ágil Scrum: Uso pelo enfermeiro em jogo educativo sobre manejo seguro de medicamentos. 2019;40:1-5.

[26] Ellen M, Glasgow S, Colbert A. The nurse-engineer : A new role to improve nurse technology interface and patient care device innovations. 2018;(November). 